\title{
PENGARUH PELATIHAN VERTICAL RESCUE TERHADAP PENINGKATAN KETERAMPILAN SEARCH AND RESCUE DALAM MENOLONG KORBAN BENCANA
}

\author{
Yuniar Wardani ${ }^{1 *}$, Purwadi ${ }^{2}$ \\ ${ }^{* 1}$ FKM UAD Kampus $3 \mathrm{JI}$ Prof DR Soepomo, SH, Warungboto Yogyakarta 55164, email: \\ yuniar.wardani@ikm.uad.ac.id \\ 2Fakultas Psikologi UAD Kampus 1 JI Kapas 9 Semaki Yogyakarta 55166, email: purwadi@psy.uad.ac.id
}

\begin{abstract}
Background: Asian countries face disasters annually. Increasing vulnerability of people in Asia, especially related to demography, social and economic change technology fastly. Any person affected by disasters, with the expected first priority is to get help meeting basic needs and either given by the general public or trained personnel such as Search and Rescue. SAR must have a variety of skills such as skills in giving Basic Life Support also Vertical Rescue.

Objective: The purpose of this study was to determine the effect of VR training to increase skills and Rescue. Methods: The type and design of the study were selected by the researchers was an experiment quasi with cross sectional approach. Variable measurement skills performed before and after the implementation of training and analyzed using Paired t test.

Results: No effect of VR training to increase knowledge $(p=0.09)$, there was the effect of VR training on the improvement of the attitude $(p=0.00)$ and there was increased influence of VR on skill improvement $(p=$ $0.00)$.

Conclusion: There was the effect of VR training to increase attitude and skills of rescue in helping victims of the disaster.
\end{abstract}

Keywords: training, VR, skills, sAR

\section{PENDAHULUAN}

Asia merupakan wilayah yang paling rentan bencana dan tempat tinggal bagi sepertiga penduduk dunia. Negara-negara Asia menghadapi bencana setiap tahunnya. Peningkatan kerentanan penduduk di Asia terutama terkait dengan keadaan demografi, perubahan tehknologi dan sosial ekonomi yang cepat. Perluasan urbanisasi dan pembangunan lingkungan dengan risiko yang tinggi merupakan sebagian dari kondisi tersebut. ${ }^{1}$ Beberapa daerah sisinya berupa pegunungan, sebagian dipenuhi oleh rawarawa. Kondisi ini sangat berpotensi untuk terjadinya berbagai bencana seperti tsunami, tanah longsor, banjir, juga gempa bumi. ${ }^{2}$ Wilayah Indonesia juga terletak di daerah tropis yang mempunyai dua musism yaitu musim hujan dan musim panas. Pergantian kedua musim ini menyebabkan perubahan cuaca, suhu, dan arah angin yang ekstrim. Kondisi ini diperparah dengan meningkatnya aktifitas masyarakat yang sering kali tidak dapat menjaga kelestarian lingkungan dan justru malah merusak lingkungan sehingga menyebabkan peningkatan risiko bencana. ${ }^{3}$

Berdasarkan Undang-Undang NO 24 Tahun 2007 saat ini telah terjadi pergeseran paradigma dalam penanggulangan bencana dari hanya menanggapi situasi saat bencana terjadi (tanggap darurat) ke pencegahan dan pengurangan risiko bencana (PRB). Dengan perubahan ini, manajemen bencana merupakan kegiatan yang dimulai sejak bencana belum terjadi. ${ }^{4}$

Setiap orang yang menjadi korban bencana, 
prioritas pertama yang diharapkan adalah mendapatkan bantuan pemenuhan kebutuhan dasar, baik yang diberikan oleh masyarakat awam ataupun tenaga terlatih seperti Tim Search and Rescue (SAR). Tim SAR adalah salah satu yang bertugas di zona berbahaya " red zone" dalam melakukan usaha mencari, menolong, dan menyelamatkan jiwa manusia yang hilang atau dikhawatirkan hilang atau menghadapi bahaya dalam musibah-musibah seperti pelayaran, penerbangan, dan bencana. $^{5}$ Hal itu menjadi suatu permasalahan besar ketika tim SAR ternyata belum memiliki keterampilan yang lengkap selain keterampilan pemberian Bantuan Hidup Dasar (Bacis Life Support atau BLS).

Kemampuan BLS adalah kemampuan seseorang yang dapat memberikan pertolongan atau tindakan dan usaha yang pertama kali dilakukan dalam kegawatdaruratan untuk mempertahankan kehidupan seseorang pada saat seseorang tersebut mengalami keadaan yang mengancam nyawanya. ${ }^{6}$ Keterampilan lain yang sangat diperlukan adalah kemampuan untuk menolong korban dari berbagai lokasi seperti korban bencana yang berada di daerah ketinggian (atap gedung pada saat terjadi korban kebakaran) atau justru kebalikannya yaitu saat korban berada di daerah lembah (korban terjatuh dari gunung, tebing dll). Penanganan korban di lokasi seperti ini memerlukan keterampilan khusus yang biasa disebut dengan Vertical Rescue.

Berdasarkan studi pendahuluan yang dilakukan pada Tim SAR persyarikatan Muhammadiyah di bawah komando Lembaga Penangulangan Bencana Pimpinan Wilayah Muhammadiyah Daerah Istimewa Yogyakarta ( LPB PWM) pada tanggal 1 Desember 2015 didapatkan data bahwa dari 35 orang anggota SARMUHDIY hanya satu orang yang sudah mempunyai sertifikat keterampilan VR. Hal ini menjadi masalah ketika SARMUHDIY mendapatkan panggilan dari Badan Penanggulangan Bencana Daerah (BPBD DIY) untuk menolong korban bencana karena secara formal yang berhak membantu hanya satu orang saja. Pada akhirnya anggota SARMUHDIY yang lain hanya dapat membantu untuk memberikan tindakan BLS saja. Permasalahan lainnya adalah hampir semua gedung yang dimiliki oleh Amal Usaha Muhammadiyah (AUM) saat ini belum dilengkapi dengan tata gedung yang tepat untuk kondisi darurat. Bahkan beberapa gedung tidak didesain dengan jalur evakuasi sehingga bila ada bencana kebakaran ataupun gempa, satu-satunya jalan adalah lewat jalan formal. Padahal pada saat bencana sangat besar kemungkinannya kita memerlukan jalur turun dengan menggunakan tali tambang dan lain-lain.

Tujuan penelitian ini adalah mengetahui pengaruh pelatihan VR terhadap peningkatan keterampilan Tim SAR yang meliputi kemampuan melakukan evakuasi satu tahap pada korban yang berada pada medan yang terjal dengan memperhatikan faktor -faktor yang memengaruhi lainnya. 


\section{BAHAN DAN CARA PENELITIAN}

Jenis dan rancangan penelitian yang dipilih oleh peneliti adalah Eksperimen semu dengan pendekatan potong lintang. Pengukuran variabel keterampilan dilakukan sebelum dan sesudah dilaksanakannya pelatihan. Lokasi penelitian yang dipergunakan adalah LPB PWM DIY yang beralamatkan di Jalan Gedungkuning 35 Yogyakarta dan waktu penelitiannya adalah dimulai pada bulan Maret sampai dengan bulan Agustus 2016. Populasi penelitian dalam penelitian ini adalah semua anggota SARMUHDIY yang berjumlah 33 orang. Teknik sampling yang dipilih adalah total sampel yaitu semua populasi, sehingga jumlah sampelnya adalah 33 orang. Sampel penelitian ini hanya terdiri dari satu kelompok saja yaitu kelompok intervensi yang pengamatannya dilakukan secara berulang atau berpasangan. Pemilihan kelompok kontrol tidak dilakukan mengingat dampak yang harus diberikan pada kelompok kontrol menyangkut biaya, waktu, dan tenaga yang tidak sedikit bila dilakukan intervensi berulang.

Analisis data yang dipilih oleh penelitian adalah analisis Uji T Berpasangan yang sebelumnya data diuji normalitasnya terlebih dahulu. Bila data ternyata tidak terdistribusi secara normal maka peneliti melakukan proses transformasi kemudian menguji normalitasnya kembali. Apabila data yang sudah ditransformasi masih tetap tidak terdistribusi secara normal maka peneliti akan menggunakan pengujian dengan anasisis statistik non parametrik yaitu Willcoxon. Pengambilan keputusan untuk menolak dan menerima hipotesis dilakukan dengan membandingkan nilai Pvalue dan derajat kemaknaan.

\section{HASIL DAN PEMBAHASAN}

Penelitian ini dilaksanakan di Kampus empat Universitas Ahmad Dahlan (UAD) Yogyakarta karena setelah melaksanakan survei lokasi di kampus satu sampai kampus lima hanya kampus satu dan kampus empat yang memenuhi persyaratan dapat dipergunakan. Kampus dua, tiga, dan lima tidak dapat dipergunakan untuk latihan VR karena bagian teras dipenuhi dengan genting sehingga apabila ada tindakan yang memerlukan VR maka Tim SAR harus menghilangkan semua genting di bagian depan.

Peserta pelatihan adalah semua Tim SAR yang tersebar dari lima kabupaten di DIY yaitu Sleman, Kotamadya, Bantul, Gunungkidul, dan Kulon Progo, masingmasing kabupaten diwakili oleh lima orang Tim SAR. Jumlah keseluruhan peserta pelatihan (responden) adalah 33 orang. Pelatihan dilaksanakan selama 4 hari dari hari Jum'at 19 Agustus sampai dengan Kamis 23 Agustus 2016 dari jam 07.00 sd jam 22.00 WIB. Nara sumber kegiatan diambil dari Tim Muhammadiyah Disaster Menajemen Central Pimpinan Pusat Muhammadiyah (MDMC PPM), Federasi Panjat Tebing Indonesia 
(FPTI), Badan Penanggulangan Bencana Daerah (BPBD DIY) sedangkan instruktur merupakan Tim SAR dari DIY dan perwakilan Jawa Tengah yang sudah tersertifikasi secara nasional. Nara sumber dan instruktur masingmasing terdiri dari 5 orang.

Materi pelatihan dilaksanakan selama 2 hari secara klasikal dan praktik-simulasi selama satu hari dan hari terakhir digunakan untuk ujian. Sebelum kegiatan dilaksanakan didahului dengan pre tes (khusus untuk aspek pengetahuan dan sikap dengan cara mengisi kuesioner secara langsung) sedangkan penilaian aspek keterampilan diambil dengan skills lab. Demikian pula pengambilan nilai di akhir pelatihan atau post tes. Analisis data penelitian dilaksanakan setelah data terkumpul, dibersihkan, dan dikoding serta dianalisis menggunakan analisis univariat dengan deskriptif dan analisis bivariat dengan menggunakan Uji T Test berpasangan. Hasil analisis berdasarkan karakteristik responden tersaji dalam Tabel 1.

Berdasarkan karakteristik repsonden sebagian besar berada pada masa remaja dan berpendidikan sebagai mahasiswa, berjenis kelamin laki-laki, dan pernah mengikuti kegiatan pelatihan SAR sebelumnya. Beberapa reponden memang merupakan Tim SAR DIY sehingga minimal responden adalah orang yang sudah terseleksi dengan berbagai persyaratan saat rekruitmen tim. Hal ini adalah logis karena memang penanganan bencana memerlukan kesehatan fisik, mental, dan sosial yang kuat, agar tidak terjadi kejadian Tim SAR yang seharusnya menolong korban ternyata malah menjadi korban yang harus ditolong hanya karena Tim SAR kecapekan yang berakibat pada kondisi sakit.

\begin{tabular}{|c|c|c|c|}
\hline NO & Karakteristik & $\mathbf{n}$ & $\%$ \\
\hline \multirow[t]{4}{*}{1} & Umur (Tahun) & & \\
\hline & $19-24$ & 19 & 58.58 \\
\hline & $25-45$ & 12 & 36.36 \\
\hline & $>45$ & 2 & 6.06 \\
\hline \multirow[t]{5}{*}{2} & Pendidikan & & \\
\hline & SMP & 2 & 6.1 \\
\hline & SMA & 18 & 54.55 \\
\hline & S1 & 11 & 33.33 \\
\hline & S2 & 2 & 6.06 \\
\hline \multirow[t]{8}{*}{3} & Pekerjaan & & \\
\hline & Pelajar & 1 & 3.03 \\
\hline & Mahasiswa & 16 & 48.48 \\
\hline & Satpam & 4 & 12.12 \\
\hline & Karyawan & 5 & 15.15 \\
\hline & Pelatih silat & 2 & 6.06 \\
\hline & Guru & 4 & 12.12 \\
\hline & Wiraswasta & 1 & 3.03 \\
\hline \multirow[t]{3}{*}{4} & Jenis Kelamin & & \\
\hline & Perempuan & 2 & 6.06 \\
\hline & Laki-laki & 31 & 93.94 \\
\hline \multirow[t]{4}{*}{5} & Pelatihan & & \\
\hline & Belum pernah & 6 & 18.18 \\
\hline & Pernah & 27 & 81.82 \\
\hline & Total & 33 & 100 \\
\hline
\end{tabular}

Hasil analisis univariat pada variabel pengetahuan menunjukkan penurunan nilai mean sesudah dilaksanakannya pelatihan. $\mathrm{Hal}$ ini dimungkinkkan terjadi karena saat pre tes ada 6 orang responden yang terlambat untuk mengikuti. Guna meminimalkan bias, responden yang terlambat disendirikan kemudian dilakukan pre tes susulan, Namun demikian hasilnya tidak dapat maksimal karena responden sempat berinteraksi 
dengan temannya sekitar 10 menit sehingga tetap memungkinkan terjadinya transfer pengetahuan yang berkaitan dengan itemitem kuesioner.

Pada variabel sikap, terjadi peningkatan nilai mean sesudah dilakukan pelatihan. Hal ini dimungkinkan terjadi, saat responden berinteraksi selama 10 menit, responden yang sudah mengikuti pretest belum sempat melakukan transfer item-item yang berkaitan dengan kuesioner aspek sikap. Pada variabel keterampilan, terjadi kenaikan nilai mean sesudah dilakukan pelatihan VR. Meskipun ada responden yang nilai keterampilannya menurun akan tetapi secara umum terjadi kenaikan dan variabilitas nilai pada masing-masing kelompok cukup besar.

Tabel 2. Deksripsi variabel pengetahuan, sikap, dan keterampilan VR pada Tim SAR.

\begin{tabular}{|c|c|c|c|c|c|c|c|}
\hline \multirow[t]{2}{*}{ No } & \multirow[t]{2}{*}{ Karakteristik } & \multicolumn{3}{|c|}{ Sebelum } & \multicolumn{3}{|c|}{ Sesudah } \\
\hline & & Mean & $\mathbf{N}$ & $\%$ & Mean & $\mathbf{N}$ & $\%$ \\
\hline \multirow[t]{3}{*}{1} & Pengetahuan & & & & & & \\
\hline & Rendah & 67.5 & 11 & 33.33 & 62.73 & 16 & 48.50 \\
\hline & Tinggi & & 22 & 66.70 & & 17 & 51.50 \\
\hline \multirow[t]{3}{*}{2} & Sikap & & & & & & \\
\hline & Tidak baik & 32.58 & 15 & 45.50 & 36.67 & 13 & 39.40 \\
\hline & Baik & & 18 & 54.50 & & 20 & 60.60 \\
\hline \multirow[t]{5}{*}{3} & Keterampilan & & & & & & \\
\hline & Tidak baik & 20.18 & 20 & 60.60 & 23.15 & 20 & 60.60 \\
\hline & Baik & & 13 & 39.40 & & 1 & 39.40 \\
\hline & Total & & 33 & 100 & & 3 & 100 \\
\hline & Hasil & ana & sis & unis & riat & den & an \\
\hline
\end{tabular}

keterampilan tersaji dalam Tabel 2. Tabel 2 menunjukkan bahwa pengetahuan tinggi sebelum pelatihan sebanyak $66.70 \%$, pengetahuan tinggi sesudah pelatihan sebanyak 51.51\%. kategori sikap baik sebelum pelatihan sebanyak $54.50 \%$, sesudah pelatihan sebanyak $60.60 \%$, dan keterampilan tidak baik sebelum serta sesudah pelatihan sebanyak $60.60 \%$.

Analisis bivariat yang digunakan oleh peneliti adalah Uji $\mathrm{T}$ test berpasangan. Uji normalitas dilakukan sebelum data diuji secara bivariat. Hasil uji normalitas menunjukkan bahwa variabel pengetahuan dan keterampilan tidak terdistirbusi secara norma sehingga dilakukan transformasi. Variabel keterampilan terdistirbusi secara normal sehingga tidak perlu dilakukan transformasi data. Hasil transformasi diuji normalitasnya kembali dan ternyata hasil akhir pada variabel pengetahuan dan keterampilan data tetap tidak terdistribusi secara normal sehingga dipilihlan uji non parametric Wilcoxon. Hasil Uji T Berpasangan tersaji dalam Tabel 3 berikut.

Tabel 3. Hasil Uji T tes pada variabel pengetahuan, sikap dan keterampilan Tim SAR dalam menolong korban

\begin{tabular}{llc}
\hline \multicolumn{1}{c}{ Variabel } & \multicolumn{1}{c}{ Jenis Uji } & P \\
\hline Pengetahuan & Wilcoxon & 0.09 \\
Sikap & T Tes berpasangan & 0.00 \\
Keterampilan & Wilcoxon & 0.00 \\
\hline
\end{tabular}

Tabel 3 menunjukkan bahwa tidak ada pengaruh pelatihan VR terhadap peningkatan pengetahuan Tim SAR $(p=0.09)$, ada pengaruh pelatihan VR terhadap peningkatan sikap Tim SAR dan ada pengaruh pelatihan VR terhadap peningkatan keterampilan Tim SAR.

Berdasarkan hasil analisis bivariat pengaruh pelatihan VR terhadap peningkatan pengetahuan menunjukkan bahwa secara statistik tidak ada pengaruh karena nilai $p=0.09$. Hal ini dimungkinkan terjadi karena 6 
responden terlambat mengikuti pretest. Meskipun sudah diupayakan untuk meminimkan kemungkinan terjadinya bias, dengan tindakan isolasi, namun upaya tersebut tidak sepenuhnya berhasil. Riwayat pelatihan SAR yang diikuti sebelumnya juga tidak banyak berperan karena pelatihan sebelumnya terfokus pada pelatihan SAR secara umum sementara pelatihan saat ini adalah pelatihan dengan keterampilan khusus yaitu VR. Peneliti juga berasumsi bahwa pelatihan bukan merupakan satu-satunya variabel yang dapat memengaruhi peningkatan pengetahuan, tetapai ada variabel lain seperti penyuluhan dan pemberian buku saku.

Hasil penelitian ini bertentangan dengan teori adalah penelitian yang hasilnya menjelaskan bahwa pelatihan dapat menambah wawasan dan pengetahuan individu dalam menghadapi bencana dan menumbuhkan minat individu karena pelatihan dapat meningkatkan semangat kerja dan membangkitkan minat dan rasa ingin mengetahui cara menolong orang dalam menghadapi bencana. Pelatihan menjadikan individu disiplin kerja, termotivasi dalam menyelesaikan masalah secara masksimal untuk mendapat hasil yang baik, tanggap pada lingkungan dan teknik penanganan korban bencana serta menjadikan individu dapat memberi arahan sesuai dengan pengetahuan yang didapatkan pada saat mengikuti pelatihan kebencanaan. Pelatihan sangat menunjang peningkatan pengetahuan dan keterampilan apabila diikuti dengan baik. ${ }^{7}$ Penelitian yang lain yang bertentangan menjelaskan bahwa pelatihan terbukti dapat meningkatan pengetahuan dan keterampilan individu. ${ }^{8}$ Pendidikan kesehatan dapat meningkatkan pengetahuan tenaga kesehatan maupun masyarakat. Pengetahuan baru dapat ditingkatkan melalui kegiatan membaca materi sehingga terjadilah perubahan perilaku yang lebih baik. Pengetahuan yang seperti ini dapat bersifat langgeng dan lebih mendalam. ${ }^{9}$

Hasil analisis pengaruh pelatihan VR terhadap peningkatan sikap Tim SAR, secara statistik menunjukkan pengaruh yang signifikan $(P=0.00)$. Peneliti berasumsi bahwa sikap adalah komponen yang tidak dengan mudah dipertukarkan karena menyangkut banyak hal termasuk keyakinan. Hal ini sangat berbeda dengan komponen pengetahuan yang secara mudah dipindahkan ataupun ditularkan. Frekwensi responden yang kategori sikapnya tidak baik menurun dan yang sikapnya baik meningkat, meskipun peningkatannya hanya 2 orang responden.

Perubahan sikap terjadi dalam waktu yang lama dan tidak secara langsung karena penilaian dan komponen sikap sangat bervariasi. Sikap cenderung berada di tengah-tengah pengetahuan dan perilaku. Perilaku dipengaruhi oleh banyak faktor di antaranya adalah pengetahuan dan sikap. ${ }^{10}$ Individu yang terpapar dengan pengetahuan 
yang baik kemungkinan akan mempunyai sikap yang baik pula. ${ }^{9}$ Minat adalah fungsi sikap terhadap perilakunya. Sikap merupakn fungsi dari kepercayaan tentang konsekwensi perilaku dengan mempertimbangkan kepentingan hasil dan merupakan fungsi harapan dari orang lain dengan mempertimbangkan motivasi untuk menerima. ${ }^{11}$ Hasil analisis pengaruh pelatihan VR terhadap keterampilan Tim SAR menunjukkan nilai yang signifikan $(p=0.00)$. Hal ini dapat dilihat dari proporsi responden yang mempunyai keterampilan baik sebelum dan sesudah dilakukan pelatihan lebih banyak dibandingkan dengan responden yang keterampilannya kurang. Salah satu keterampilan VR adalah keterampilan memberikan BHD, dan keterampilan tersebut sudah didapatkan saat responden mengikuti pelatihan dasar SAR. ${ }^{15}$ Keterampilan responden meningkat karena semua responden diberikan kesempatan untuk mempraktikkan keterampilan VR dan dinilai per individu. Meskipun kenyataannya masih ada responden yang pada awal kegiatan takut berada di ketinggian. Guna menjaga agar keterampilannya dapat dipertahankan maka responden harus senantiasa memperdalam keterampilannya dengan rajin berlatih.

Hasil penelitian ini sesuai menjelaskan bahwa pelatihan dapat meningkatkan keterampilan individu dalam melakukan suatu keahlian. Pelatihan dapat mendukung keterampilan yang dimiliki oleh lifeguard dalam menjalankan tugasnya. ${ }^{12,13}$ Dalam menolong korban dan tujuan lainnya adalah untuk memberikan kenyamanan kepada pengunjung atau khalayak ramai. Bila khalayak ramai nyaman dan terjaga dari risiko terjadinya bencana maka pelayanan kepada pengunjung akan semakin meningkat. ${ }^{14}$ Cara individu mempersepsi akan memberikan motivasi pada perilakunya. Kesiapan untuk melakukan tindakan berasal dari persepsi individu akan suatu masalah. Individu dapat melakukan perubahan perilaku dengan didasarkan pada konsistensi internal antara kepercayaan, sikap dan perilakunya karena secara psikologis individu akan merasa nyaman. ${ }^{11}$ Pengetahuan, sikap, dan keterampilan individu merupakan kunci dalam kehisuoan sehari-hari. Apabila setiap individu senantiasa menjaga perilakunya maka individu tersebut akan terhindar dari berbagai kemungkinan buruk. ${ }^{9}$

\section{KESIMPULAN}

Berdasarkan hasil penelitian dapat disimpulkan bahwa tidak ada pengaruh pelatihan VR terhadap peningkatan pengetahuan dan ada pengaruh pelatihan VR terhadap peningkatan sikap dan keterampilan Tim SAR dalam menolong korban bencana.

\section{KEPUSTAKAAN}

1. Wuryanti, T, Kerangka Aksi Hyogo,Pengurangan Risiko Bencana 2005 -2015 Membangun Ketahanan Bangsa dan Komunitas Terhadap Bencana, Masyarakat Penanggulangan Bencana Indonesia, Jakarta. 2008

2. Probosiwi, R, Keterlibatan Penyandang Disabilitas Dalam Penangulangan 
Bencana, Jurnal Penanggulangan Bencana, Volume 4 Nomor 2, November 2013, Halaman 13-22.

3. Lumawa, SH, Rekruitmen SAR, Jurnal Eksekutif Vol 1 No 42015.

4. Dahlan, S., Kumaat, L., Onibala, F., Pengaruh Pendidikan Kesehatan $T$ entang Bantuan Hidup Dasar (Bhd) Terhadap Tingkat Pengetahuan Tenaga Kesehatan Di Puskesmas Wori Kecamatan Wori Kabupaten Minahasa Utara, Ejournal keperawatan (e-Kp) Volume 2, Nomor 1. Februari 2014, Halaman 1 -8.

5. BPBD Provinsi Jawa Tengah, Buku Panduan PelatihanTeknik Vertikal Dan Vertical Rescue Tingkat Dasar Bagi Potensi SAR Di Jawa Tengah, Pelatihan SAR. 2013

6. Guyton, A. C., Hall, J. E. Buku ajarFisiologi kedokteran (Eds. 11) (Irawati, Dian Ramadhani, Fara Indriyani, Frans Dany, Imam Nuryanto, Srie Sisca Prim a Rianti, Titiek Resmisari \& Y. Joko Suyono, Penerjemah). Jakarta: EGC. 2008

7. Nurchayati, S., Junaidi, Rahayu., S, 2006, Upaya Peningkatan Pengetahuan Dan Keterampilan Masyarakat Dalam Memberik an Bantuan Hidup Dasar Pada Kejadian Gawat Darurat Kelautan Di Kelurahan Cilacap Kecamatan Cilacap Selatan Kabupaten Cilacap Tahun 2006, LaporanPengabdian dibiayai oleh dana DIPA Kopertis Wilayah VI tahun anggaran 2006.
8. Saputra, H, Efektifitas Pelatihan kebencanaan pada pegawai BPBD Bengkulu,2015.

https://www.google.co.id/search?q=lubma zal.com.

9. Wardani, Y., Sofiana, L, Ayu, SM., Gustina, E, Wibowo, M., Efektifitas Buku Saku sebagai Media Promosi Kesehatan dalam Peningkatan pengetahuan tentang HIV pada Tukang Cukur Di Lota Yogyakarta, Yogyakarta. 2015

10. Ulum, MC., 2010, Governance dan Capacity Building dalam Manajemen Bencana Banjir Di Indonesia, Jurnal Penanggulangan Benca na, Volume 4 Nomor 2, November 2013, Halaman 512.

11. Emilia Ova, Promosi Kesehatan Dalam Lingkup Kesehatan Reproduksi, Pustaka Cendekia Press Yogyakarta. 2010

12. Fitri, MH dan Mardiana, 2011, Pelatihan Terhadap Keterampilan Kader Posyandu, Jurnal KEMAS 7 (1) 2011 Halaman 22 27.

13. Sukiarko, E. Pengaruh Pelatihan dengan Metode Belajar Berdasarkan Masala $h$ dalam Kegiatan Kader Gizi Posyandu: Studi di Kecamatan Tempuran Kabupaten Magelang. Jurnal Media Medika Indonesia . 42 (3): 103-147. 2007

14. Choirian, N, Junaidi, S., Rahayu, S, Manajemen Lifeguard Pada Water Blaster Kota Semarang, Journal of Sport Sciences and Fitness, JSSF 2 (1) 2013, Hal 39-43. 